\title{
Flâneur nadrzeczywistości. Vítězslava Nezvala surrealne wędrówki po Pradze
}

\begin{abstract}
Gawarecka Anna, Flâneur nadrzeczywistości. Vitězslava Nezvala surrealne wędrówki po Pradze (Flâneur of the Surreality. Vítězslav Nezval's Surreal Walks around Prague). "Poznańskie Studia Slawistyczne" 18. Poznań 2020. Publishing House of the Poznań Society for the Advancement of the Arts and Sciences, Adam Mickiewicz University, pp. 103-123. ISSN 2084-3011.

In the surrealistic period of his literary work Vítězslav Nezval, following the French formula of presenting Paris as an archetypical modern city, published textual passage Pražský chodec (1938) which title is taken from the famous Apollinaire's story but its narrative schema resembles the Louis Aragon's Paris Peasant. In opposition to avant-garde ideas of the perfect urbanization projects connected with the technological progress and futurological utopias Nezval tries to show Prague (more mysterious and surreal in his eyes than the capital of France) as a space of living literary tradition, full of lieux de mémoire and traces of long past events. Walking around urban streets, alleys or bridges often regarded as the typical surrealistic activity, becomes here an instrument of evoking these memories and it is also treated as a metaphor of poetic creation.
\end{abstract}

KEYwords: textual passage; surreality; memory; tradition; urban text

Kdo neviděl, jak tyto sochy opouštějí v nočních hodinách za jistých, v kalendáři předem neoznačených dní své sebevražedné podstavce, aby se vmísily mezi noční pasanty, aby se rozhlédly po dvanácti pražských mostech (není je všecky odtud vidět), nikdy nebude rozumět mé poezii (Nezval, 1981, 73).

W „fantasmagorycznym spacerowniku”, jak można, nie znajdując bardziej adekwatnego terminu gatunkowego, określić opublikowany przez Vítězslava Nezvala w 1938 roku tekst opatrzony, na wzór opowiadania Guillame'a Apollinaire'a, tytułem Pražský chodec (Praski przechodzień), skąd pochodzą zacytowane słowa, motyw poruszających się 
posągów z mostu Karola w Pradze powraca dwukrotnie ${ }^{1}$. Po raz drugi, w przywołanej tu wypowiedzi, staje się swoistym, gdyż ukrytym (jako parentetyczne zdanie wtrącone) wśród meandrycznej opowieści o (hipotetycznej i/lub odbytej wyłącznie w wyobraźni narratora) wędrówce przypadkowo wybranego wśród tłumu nieznajomego przechodnia, utożsamionego z sobowtórem czy raczej w Jungowskim duchu rozumianym autorskim Cieniem², metaliterackim wtrętem, określającym „warunki progowe", które muszą zostać spełnione, by między surrealistyczną poezją a jej potencjalnym (projektowanym) odbiorcą zaistnieć mogła „nić porozumienia". Nawiązanie takiej więzi wymaga zaś uznania (zadeklarowanego przez owego odbiorcę) prawa poety do dokonywania w reprezentowanej rzeczywistości niczym nieograniczonych przesunięć, deformacji i uniezwykleń dowodzących, że moc kreacyjna artysty potrafi odzwierciedlić czy raczej wcielić w życie (na zasadzie ontycznej adekwatności) ideę surréalité.

W przypadku pierwszym natomiast wizja poruszających się kamiennych figur, stanowiąc finalną część rekonstrukcji widoku, rozpościerającego się z tarasu jednej z nadwełtawskich kawiarni, pokazuje, jak wielką

${ }^{1}$ Badaczka współczesnych wzorców (para)literackiej reprezentacji miasta, Katarzyna Szalewska, stwierdza, że „,[n]owoczesny pejzaż gatunkowy związany z doświadczeniem urbanistycznym, w którego centrum sytuuję tekstowy pasaż, na swych obrzeżach ma złożone konfiguracje form wypowiedzi o odmiennych dominantach kompozycyjnych i stylistycznych. $\mathrm{Z}$ jednej strony będą to bedekerowo-pasażowe hybrydy w rodzaju spacerowników, a więc gatunki z pogranicza użytkowych, z drugiej - te, w których intelektualna flâneurie miesza się z dyskursem stricte naukowym" (Szalewska, 2017, 26-27). Pod wieloma względami Nezvalowski Pražský chodec bliski jest opisywanemu przez Szalewską tekstowemu pasażowi, określanemu jako „forma spotkania rzeczywistego miasta z miastem wyobrażonym, przeczytanym i przemyślanym" (Szalewska, 2017, 25). Różni się jednak od niego i zarazem upodabnia do spacerownika ze względu na wyraźnie edukacyjny charakter, nastawiony na wykształcenie w wyobraźni czytelnika pożądanych sposobów postrzegania i odczytywania sensów obserwowanej przestrzeni miejskiej.

${ }^{2} \mathrm{Cf}$. „Proč čte již potřetí za sebou nápis, hlásající nad jednopatrovou hospodou, za jejímž oknem se třpytí nazlátlá vepřová pečeně a vlašský salát, že jsou tu levné hostinské pokoje, když se vzdouvá jeho kapsa (nemá revolver) klíčem od moderního domu, kam má právo vstoupiti, aby si vykourril vyhaslou cigaretu, již upustil před dvěma měsíci v koupelně (pamatuje se na to přesně!). Nebude stoupat po schodech k pokojíku Jana Nerudy, nebot' není výletníkem. [...] Nezajde k Mecenáši, nebot' není naladěn dát na sebe mrkat zeleným očím sůvy a připraviti se o to málo peněz, kterých nemá nazbyt. Ostatně není zvykem, aby číšnice nosila Stínu bouef à la Stroganov s chlazeným vínem” (Nezval, 1981, 72-73). 
(i przez surrealistów w wyjątkowej mierze eksponowaną ${ }^{3}$ ) rolę w percepcji ,widzialnego świata” odgrywa złudzenie optyczne:

Nelze spočísti, kolik různých a nečekaně spojených podrobností tvoří náš sen. Tyto podrobnosti mizí a divák má pocit, že život stojí za to, aby byl žit. Těžko říci, čím je komu u hostů této terasy nabílená budova dotýkající se vody, tak málo městská budova, jež by mohla býti právě tak starým mlýnem jako součástí nějakého venkovského dvorce. Jiná budova, již zcela izolovaná a ponořená do husté zeleně, je v těchto místech dvoupatrovou archou, v níž by člověk rád přespal léto. Dva nebo tři rybáři, spíše vzpomínky na holandský obrazek než pravděpodobnost skloněná nad prutem, přicházejí sem místo venkovské písničky sprostředkovat styk mezi naším dětstvím a středověkem, jehož obyvatelé nám kračejí vstříc po Karlově mostě. Ano, ty sochy jdou, ty sochy se pohybují. Pohybují se, poněvadž Karlův most není bez chodců. Avšak jakmile vstoupíme sami na Karlưv most, tento div ustane. Kdybychom chtěli, jsme v divadle (Nezval, 1981, 51-52).

Przeniesienie narzędzi dynamizacji/ożywiania tego, co w potocznym doświadczeniu uznawane bywa za nieruchome/martwe, Nezvalowi-surrealiście kojarzące się nierzadko zresztą z działalnością magiczną i teatralnym nacechowaniem przestrzeni (o widowisku w miejscu odnalezionym mówi w podobnych przypadkach Cathy Turner [2010, 23]), ze strategii mimetycznego odzwierciedlania empirii w sferę rejestracji subiektywnego, uwarunkowanego prawami optyki, wrażenia ułatwia poecie zaprojektowanie odnowionego wizerunku miasta, po części „nieopatrzonego” i wywikłanego z utartych nawyków poznawczych, po części zaś - zbudowanego $\mathrm{z}$ odpowiednio dobranych kulturowych reminiscencji. Pod pewnymi względami zatem Pražský chodec oferuje odbiorcy osobliwy przewodnik po czeskiej stolicy, w którym wyeksponowane (czy w ogóle zauważone) zostają wyłącznie miejsca twórcy bliskie, wywołujące (aktualnie lub w przeszłości) całkowicie prywatne i jednostkowe reakcje

\footnotetext{
${ }^{3}$ Należy wszak pamiętać, że od podobnej analizy złudzenia optycznego dzieje kierunku właściwie się zaczynają, jak przynajmniej wynika ze znanych, zamieszczonych w Manifeście surrealizmu, słów André Bretona: „Któregoś wieczoru przed zaśnięciem doszło mnie [...] dość dziwaczne zdanie bez żadnego związku z wydarzeniami, w których [...] brałem w tym czasie udział [...]. Uprzytomniłem je sobie błyskawicznie i byłem już gotów o nim zapomnieć, kiedy zastanowił mnie organiczny charakter tego zdania. [...] To mnie rzeczywiście zadziwiało; dziś już, niestety, nie pamiętam dokładnie tego zdania, było to coś w rodzaju: «Jest człowiek przecięty na dwoje przez okno», ale nie zawierało żadnej wieloznaczności, związanej z dość bladym wyobrażeniem wzrokowym człowieka, który idzie przecięty w połowie wysokości oknem prostopadłym do osi jego ciała” (Breton, 1976, 73-74).
} 
emocjonalne. Owe lieux de mémoire korespondują co prawda $\mathrm{z}$ autorskim doświadczeniem onirycznym i z zakodowanymi w indywidualnej pamięci „okruchami” wspomnień, ale niekoniecznie przynależą do zasobu uznanych turystycznych atrakcji i dodatkowo najczęściej w ogóle nie przywodzą na myśl praskiego genius loci ${ }^{4}$. Nezval, zdając sobie sprawę z niekonwencjonalnego wymiaru swej propozycji ,przeprogramowania” sensów zaszyfrowanych w pejzażu miejskim i wyprzedzając przewidywane zarzuty płynące ze strony czytelników rozczarowanych nietypowym charakterem spacerownika, przyznaje explicite, że u źródeł jego inspiracji leżało ukazanie obrazu „innej Pragi”, odmiennego od jej rozpowszechnionego (również wśród mieszkańców) postrzegania w kategoriach konglomeratu sztampowych, utrwalonych w dyskursach memorialnych, zsemiotyzowanych topoi. „Praskość” bowiem nie koncentruje się wokół kilku uschematyzowanych w swych znaczeniach architektonicznych emblematów (które, nawiasem mówiąc, zostają w tekście odkrywczo odczytane i pod zaskakującym kątem obejrzane), ale ulega swoistemu rozproszeniu, znajdując swe nieoczekiwane inkarnacje $\mathrm{w}$ na pierwszy rzut oka niepozornych i mało ważnych lokalizacjach:

Snad řeknete, že vás vodím půvaby (možná, že přiznáte tomu, co má v moci dojímati mne, větší nebo menší půvab), které nemají nic „typicky pražského”, které bychom mohli, chcete-li, potkati kdekoliv jinde mimo toto město. Přiznám se, že jsem velmi št’asten, nalezl-li jsem je právě v Praze. [...] Nebot' nic z toho, co si nás osobuje zaujati měrou, jejíž velikost nebo malost potvrzuje velikost nebo malost našeho štěstí, by nežilo oním jedinečným životem, kdyby to nebylo postaveno do jistých a nejiných souvztažností, do podmínek tak či onak odlišných. Trvám na tom, že kouzlo jistých bezděčných vzrušujících situací pramení pro mne právě z toho, že že jsem se s nimi setkal v Praze (Nezval, 1981, 58).

${ }^{4}$ Do pewnego stopnia Nezvalowska metoda literackiego poruszania się po mieście przypomina postępowanie sytuacjonistów „rozwijający[ch] ideę miejskiego dryfowania” (Frydryczak, 2002, 86-87) i wiele inspiracji czerpiących z surrealistycznych eksperymentów (cf. Hrdlička, 2009, 101) oraz działania twórców tzw. Mis-Guide’ów, których ,głównym zainteresowaniem jest «mitogeografia» - przez którą rozumiemy nie tylko jednostkowe doświadczenie przestrzeni, ale także dzielone z innymi mitologie przestrzeni, które nadają jej znaczenie. Nasz przewodnik sytuuje to, co osobiste, fikcyjne i mityczne na równi z rzeczywistą historią miasta. [...] Można jednakże czytać Mis-Guide również jako otwarte zaproszenie do powtórnego wyobrażenia sobie i «przerobienia» miasta przy równoczesnym odkrywaniu go na nowo: wówczas staje się ono «przestrzenią potencjalną»" (Turner, 2010, 251). 
Liczy się zatem nie tyle reprezentatywność praskich zabytków i atrakcji turystycznych poświadczona bagażem literackich, artystycznych i historycznych skojarzeń utrudniających dotarcie do niezapośredniczonych przez kulturowe filtry sposobów widzenia przestrzeni miejskiej, ile funkcja, jaką dla osobistego doświadczenia narratora spełniają rozmaite katalizatory emocjonalnych i imaginacyjnych procesów - a zatem poszczególne uliczki, placyki i zaułki. Gra między wyznacznikami lokalności i uniwersalnego, by tak rzec, krajobrazu urbanistycznego, toczona na kartach spacerownika, niezależnie od ukrytego w niej ostrza polemiki skierowanej przeciwko wyznawcom skonwencjonalizowanego wyobrażenia o „złotej, stuwieżowej Pradze”, prowadzić ma, jak wyjaśnia autor, do „odświeżenia” sfery uczuciowej (dziś w takich przypadkach chętniej mówi się o domenie afektów) i do wydobycia ze ,spostrzeżeniowego niebytu” omijanych najczęściej podczas ,standardowych” tras przechadzek, swoistych tranzytowych nie-miejsc, których istnienie, choć uważane za „mało znaczące”, współtworzy niepowtarzalną atmosferę stolicy:

\footnotetext{
Kdybych otevřel noviny, dočetl bych se na všech řádcích, že hrozí válka, hrozí zničit tyto terasy, ten Petřín, ty hradčanské věže. Hrozí zničit to město, jímž chodím. A snad právě toto nebezpečí působí, že již dva roky, dvě jara a dvě léta, jsem svědkem, jak se ve mně rodí „nový cit” k Praze. Tento „nový cit” mne nutí, abych se zastavoval před Prahou jako před houslemi - a abych tiše, jako se zkouší ladění, brnkal na její struny, at' je jimi cokoliv. Tento „nový cit” činí ze mne ladiče, který převádí vše, co potkává, do jediné tóniny: do tóniny dojetí bez přecitlivělosti. Tento „nový cit”, který se zhmotňuje ve vteřinových setkáních s čímkoliv, nerozlišuje krásu podle toho, jak je důležitá či nedůležitá, bloudí pod širým nebem a středem samého života, tento „nový cit” dělá ze mne pražského chodce (Nezval, 1981, 16).
}

W nowym uczuciu-spojrzeniu, metaforyzowanym dodatkowo za pomocą synestezyjnego, wzbogacającego paletę doznań zmysłowych, motywu strojenia skrzypiec, istotne okazuje się „cokolwiek”, czyli wszystko, co owe emocje władne jest ewokować. Istotność ta wzrasta zaś niepomiernie w obliczu niebezpieczeństwa zaniku, które grozi wszystkim bez wyjątku cennym i pozornie bezwartościowym - komponentom praskiej topografii. Świadomość tego zagrożenia, charakterystyczna zresztą dla literatury czeskiej w drugiej połowie lat trzydziestych, aczkolwiek zaskakująca być może w wypowiedzi surrealisty, zmusza niejako (poetę, a więc i „prowadzonego" po miejskich zakamarkach czytelnika) do podejmowania 
poznawczych pieszych wypraw owocujących przy okazji reaktualizacją dyskursu memorialnego, którego rangę awangardowe poczynania Nezvala (i jego devětsilowskich towarzyszy) z wcześniejszego, poetystycznego, etapu twórczości, osłabiły co prawda, ale nie zdołały całkowicie zdeprecjonować, ani - tym bardziej - unieważnić:

Probud' se, tolik zahlazená paměti Prahy! Říkáme-li sen, je to kromě dneška, jenž by si rád podrobil tak nemilosrdně všecky naše síly, také všechen pravěk v nás. Jedině tomuto pravěku vděčí dnešní den za to, je-li něčím hlubším, ozvučnějším než pouhá smyslová radost nebo úzkost, je-li, stává-li se básní. Až procitne pamět' Prahy v jejich dětech, $\mathrm{v}$ jejích dnešních dětech, obrovské poklady poezie budou vytaženy na denní světlo. Když se při slově Pařǐž zachvívají lidská srdce, oč bývá vyslovováno tvé jméno, Praho, tajemnější než všecka města, $s$ uštěpačnými rty anebo s chvástavou žvanivostí! To proto, že každý pařížský kámen je poznamenán polibkem dobrodružství, které je v moci básníků - a že pod pražskými střechami je zohyzdila bez rozpaků čiperná hydra banality (Nezval, 1981, 34).

Pamięć, zarówno ta kulturowa, jak i indywidualna odgrywa bowiem kluczową rolę w Nezvalowskich wędrówkach po mieście, a jego fascynacje zaczynają obejmować nie tylko, a nawet nie przede wszystkim - eksponowane wcześniej znamiona metropolitalnej nowoczesności, ale także dzielnice starsze, wegetujące ,na tyłach” owej fasadowej reprezentatywności oraz „niczym się niewyróżniające”, pozbawione otoczki historycznych reminiscencji, peryferie 5 . Ich swoista „memorialna jałowość” czyni z nich bowiem dogodny teren operacji znaczeniotwórczych, zapraszając do nadawania im nieobecnych dotąd sensów, korespondujących z imaginacyjnym uniwersum surrealizmu:

Jaká škoda, že ani jediné ze tří míst Vinohrad, na nichž jsem bydlel, ani Košíře, ani Smíchov, ani Nusle Údolí nenašly si v mé obraznosti či v některém literárním díle

${ }^{5}$ Przyjęta przez Nezvala strategia wyboru spacerowych tras przypomina postawę flâneura, którego sztuka (flânerie), w opinii Katarzyny Szalewskiej, ,jest rozkoszą, ale i szkołą spojrzenia. Nie patrzenia, nieuważnego, rozproszonego w nadmiarze miejskiej ikonosfery, niewidzącego naprawdę, bo ślizgającego się po powierzchni, fasadzie miasta, lecz spojrzenia wyćwiczonego w selekcji materiału zebranego w wyniku percepcji przestrzeni. [...] Umiejętność połączenia percepcji przestrzeni niezdeterminowanej sugestiami z przewodników, albumów [...] z przenikliwością oddalają flâneura [...] od turysty łudzonego pięknem fasad, kierującego swój wzrok zawsze ku temu, co już obejrzane, przemyślane, znane z reprodukcji. [...] Ujawnia spojrzenie flâneura z jego całym uwikłaniem w historyczność. Spojrzenie prowadzące ku tym miejscom przestrzeni, które są śladem przeszłego, przestrzenią transgresji, ku miejscom pamięci miasta” (Szalewska, 2009, 48-49). 
prostředníka, který by mi svou blahodárnou magičností umožnil snášet alespoň se sebemenším básnickým vytržením nevlídné životní podmínky, k nimž jsem byl připoután v oněch čtvrtích. Bylo nutno, abych si teprve snem z prvého zpěvu Edisona sám ozářil dosti dlouho poté, kdy jsem se z nich vystěhoval, Košíre imaginárním průvodcem, jejž potkala má imaginace na mostě Legii. A měl-li jsem přiznati časem básnický půvab Smichovu, musil jsem cestovati do Pařiže a vzpomenouti si na Montparnasse na tuto pražskou čtvrt, tak dlouho němou pro mne (Nezval, 1981, 40).

Sensy te, jak wynika z Nezvalowskich utyskiwań, obligatoryjnie pojawiają się dopiero po dokonaniu ,literackiej transkrypcji” miejskiej terra incognita $\mathrm{w}$ przestrzeń kulturowo oswojoną i opracowaną. $\mathrm{Z}$ tego punktu widzenia zaś patrząc, Pražský chodec pełnić zaczyna funkcję sui generis bedekera, wytyczającego turystyczno-spacerowe marszruty na podstawie lektury kanonicznych dzieł praskiej poezji i prozy. Wstępne zwierzenia narratora sugerują zresztą, że wszystkie zaprojektowane w dziele wędrówki po Pradze mają charakter mentalny i „odbywają się” po części we wspomnieniu, po części zaś - stanowią rezultat ,pracy” wykonanej w wyobraźni, zależnej nie tylko od spontanicznych (jak przystało surrealiście) impulsów płynących z głębin nieświadomości, lecz również z rozmaitych tekstów kultury - od dzieł literackich i muzycznych począwszy, a na biografiach znanych praskich pisarzy skończywszy:

Tak objeví člověk tu či onu legendu ponurou nebo dojemně utichlou, tak se vydá muž připoutaný k židli na potulky za něčím, co již nečekal spatřiti. Miluji Prahu legend, když se s nimi setkávám takto. Upraveny jakoby jednou provždy v starých knihách se zlatými iniciálami, tyto legendy vstupují na ulici a působí, že je půjdu rád zhlédnouti na vlastní oči, jakmile ustane dešt'. Což to není kouzelné vkročit jen tak, bez dlouhého zjišt'ování, co se právě hraje, do Stavovského divadla, abychom tam upřeli oči na místo, kde zaklepal Wolfgang Amadeus Mozart na notový pult při prvém představení Dona Juana? Anebo za dne, jehož nebesa neslibují ani bouři, ani dobrodiní blankytné lučinky, toulati se tam někde na místech bývalého Františku, abychom si zpř́ítomnili půvab Máchovy sentimentální cesty za Marinkou [...] V tomto smyslu rozumím pojmu tradice, v níž vidím snové, tajemné zmrtvýchvstání všeho, co může, co má sílu, at' sebevíc zapomenuto, ujmout se nás ve chvílích, kdy jsme nejčistší, to jest kdy naše touha nás vrací až k nejdavnější paměti našich chův a prastarých knih, k nejdávnější paměti toho, čím jsme sami z dob, kdy nás zaujímala ještě více prostá písnička a pravěk starých pověstí než těžko proniknutelné zmatky každodenního života (Nezval, 1981, 12) ${ }^{6}$.

${ }^{6}$ Cf. też: „Co je to býti chodcem, uvědomuje si člověk, jakmile je osudně připoután k židli. Tato židle je opakem trůnu, je to pracovní verpánek - a život prchá. Úloha chodce se zdá býti snad proto tak ideální, poněvadž život prchá. Když jdeme - a hlavně když jdeme po cestě 
Przekształcając spacer po Pradze w tropienie pamięciowych śladów, które zwykłą, codzienną przechadzkę nobilituje bez mała do rangi pielgrzymki do miejsc dla narratora świętych, Nezval na pierwszy rzut oka poddaje zakwestionowaniu funkcję, jaką „miejskim włóczęgom” nadali surrealiści. W ich oczach bowiem, jak pisze Agnieszka Taborska, spacer taki

był [...] czynnością irrealną. Wierni propagowanej przez Rimbauda koncepcji dépaysement, błądząc bez celu, wcielali w życie ideę ,,automatycznej wędrówki”, sprzyjającej przemianie codziennej rutyny w poezję. [...] Włóczęga po ulicach zawsze prowadziła do niespodziewanego spotkania, znaczącej wymiany spojrzeń, codziennie potwierdzającej wagę przypadku (Taborska, 2007, 157) ${ }^{7}$.

Innymi słowy, by miejska wędrówka nabrała stricte surrealistycznego wymiaru, spełnione zostać muszą odpowiednie i w rygorystyczny sposób przestrzegane (należy pamiętać, że Bretonowska doktryna prądu wymagała od jego przedstawicieli czy raczej wyznawców bezwzględnego niemal podporządkowania się) warunki. Wśród nich zaś kluczową rolę odgrywała wzmiankowana przez Taborską „,bezcelowość”, a zatem poruszanie się po mieście nie tylko bez z góry powziętego planu (o praktycznym jego wymiarze nawet nie wspominając), lecz także - przede wszystkim! „Z pominięciem” wszelkich racjonalnie motywowanych decyzji. Im bardziej wielokierunkowa, okrężna, chaotyczna i lekceważąca topograficzną, administracyjnie zadekretowaną, hierarchię ważności przestrzeni centralnych i peryferyjnych będzie bowiem trasa kolejnej (zawsze nowej i odmiennej od poprzednich) przechadzki, w tym większym stopniu zbliży się ona do innych, tak wysoko cenionych przez surrealistów „automatyzmów” ze sławnym écriture automatique na czele i tym silniej uobecni się w niej

\footnotetext{
bez cíle -, nepatrné obrazy naši touhy, jež se nám vtírají do kroku, působí, že přestáváme vidět její konec - její opak" (Nezval, 1981, 12).

${ }^{7} \mathrm{~W}$ innym miejscu badaczka pisze zaś, że „[p]eregrynacje bez celu, czynność surrealistyczna par excellence, pielgrzymki do miejsc wybranych: parków, kawiarń, tanich kin i teatrzyków, obskurnych hotelików z pokojami na godziny i pasaży, najbardziej niekwestionowanego królestwa przechodniów, wprawiały młodych poetów w szczególny stan ducha. Pozwalały uchwycić poezję codzienności oraz istotę surrealistycznej wrażliwości: cudowność, czyli poczucie poetyckiej tajemnicy, umożliwiające ucieczkę z podległej logice egzystencji, zrywające z estetycznymi stereotypami, racjonalnymi nawykami i ograniczeniami wrażliwości” (Taborska, 2007, 205).
} 
oddziaływanie „przypadku obiektywnego” świadczące o wiarygodnym podłożu sądów o istnieniu nadrzeczywistości ${ }^{8}$. Współczesne miasto dostarcza zaś wielu okazji do rozmaitych przygodnych spotkań czy obserwowanych przelotnie, intrygujących, gdyż pozbawionych „kontekstu interpretacyjnego", wymykających się rutynowym przyzwyczajeniom, sytuacji, w których swój wyraz i ucieleśnienie znajduje surrealna cudowność/niesamowitość, rodząca się spontanicznie we wnętrzu codzienności zyskującej dzięki temu niezaprzeczalny poetycki (identyfikujący de facto życie miasta z poezją) potencjał:

V tom městě, v obrazci nejkratšího spojení dvou bodů, na mapě prímek, nazvané skutečný život, na půdorysu toho města, které ti prǐřkl osud, jsi potkával v nečekaných chvílích překvapující výjevy, bytosti, které se ti zdály být náhlé nadpřirozenými. Udála se ti setkání, př̌ nichž jsi vystupoval na jevište nepravděpodobných féerických her, zažil jsi slavnostní osvětlení, měls iluze už dávno viděného, takže jsi přestával kráčeti od bodu $\mathrm{k}$ bodu, $\mathrm{z}$ místa určení na místo určení a spatřil město nazývané Praha $\mathrm{v}$ té přeludné podobě, jakou mělo, když si na ně hleděl do kukátka (Nezval, 1981, 35).

„Miasto zwane Pragą” oglądane ,jak niegdyś przez wizjer fotoplastykonu" (Nezval wielokrotnie przywołuje w dziele wspomnienia z dzieciństwa, zgodnie z surrealistyczną filozofią twórczą sytuując w najwcześ-

${ }^{8}$ Krystyna Janicka dowodzi, że „,[d]oświadczalny wgląd w to, czym jest nadrzeczywistość, daje nadrealistom nie tylko marzenie senne i rozmaite stany alienacji mentalnej, a pośrednio świadomość dziecka i ludów prymitywnych, ale wgląd ten dają także występujące w życiu człowieka niewyjaśnione jeszcze zjawiska, zwane zwykle przypadkiem, trafem, zbiegiem okoliczności” (Janicka, 1985, 110). Badaczka zwraca też uwagę na podwójny charakter ,zjawisk określanych przez Bretona mianem «przypadek obiektywny», to jest na ich przynależność jednoczesną do dwu ciągów (serii) przyczynowych - naturalnego i ludzkiego lub realnego i idealnego, a przez to wskazuje na ich podwójną naturę: należą bowiem one zarówno do tego, co zwykliśmy zwać światem zewnętrznym, obiektywnym, naturalnym, jak i tego, co zwiemy światem wewnętrznym, subiektywnym, psychicznym. Ta kwalifikacja zdarzeń wskazuje nieodparcie, że prezentują się one nadrealistom jako mikroodbicia nieantynomicznej surréalité" (Janicka, 1985, 111). Bezpośrednio z życiem miasta i utopią nadrzeczywistości wiąże natomiast surrealistyczną ideę przypadku obiektywnego Michel Carrouges: „Když Breton bloudí uvnitř pařǐžských zdí i za nimi, nejvíce mu záleží na objevování fenoménů, jimiž se v plném denním světle a v ruchu ulice projevují tajemné zásady okultních sil: znepokojivé reminiscence, ohromující shody okolností, prorocké předtuchy. Objektvní náhoda je souhrn těchto fenoménů které jsou projevem vpádu zázračna do každodenního života. Skrz ně se totiž ukazuje, že člověk ve dne kráčí středem sítě neviditelných sil, které by stačilo odhalit a zachytit, aby konečně mohl před zraky světa vítězně postupovat i k nejvyššímu bodu" (Carrouges, 2015, 172). 
niejszym okresie życia źródła wszelkich późniejszych inspiracji) jawi się jako terytorium, w którym administracyjnie narzucony porządek (linie proste zachęcające do obierania najkrótszej drogi do wyznaczonego celu) utrudnia (wbrew zamierzenioniom planistów) autentyczne doświadczanie, a zatem też: oswojenie ,wyznaczonej przez los” przestrzeni ${ }^{9}$. Tę bowiem należy dopiero, odrzucając „instucjonalnie poprawny” ład, spersonalizować, czyli wypełnić osobistymi przeżyciami i wspomnieniami czyniącymi z wyjałowionej z emocji, poddanej ściśle racjonalnemu zorganizowaniu topografii urbanistycznej, domenę zadomowienia ${ }^{10}$. Jednym z narzędzi takiej domestykacji miasta pozostają zaś spacery, nie tylko umożliwiające jego poznanie, lecz także - porównywane do urządzania siedziby mieszkalnej - zagospodarowanie, które z pojęciem domu i „braniem świata w posiadanie" bezpośrednio się kojarzy:

Jako člověk projde mnoho obchodů s pohovkami, a klavíry a s ramy, zařizuje-li byt pro sebe nebo pro ty $\mathrm{k}$ nimž je poután jednym $\mathrm{z}$ těch vztahů, které vyplývají z jeho osudu,

${ }^{9}$ Jak bowiem twierdzi Tadeusz Sławek, „w każdym mieście są dwa miasta [badacz, za Jerzym Giedroyciem, nazywa je «dolnym» i «górnym» - przyp. A.G.]: jedno, które odpowiada starannie wyrysowanym na planach przebiegom ulic, w którym życie jest ściśle regulowane administracyjno-komunikacyjnymi dyrektywami, i drugie - które odsłania się dopiero uważnemu spojrzeniu, w którym wspomniane regulacje ulegają znamiennym przemianom. Gdyby pójść za metaforą przebudzenia towarzyszącą (np. u Thoreau, ale także u Blake’a) filozofii percepcji, powiedzielibyśmy, że pierwsze miasto, chociaż pozornie oddane jawie i jej twardym wymogom, pozostaje w stanie «snu», z którego otrząsa się dopiero w swej drugiej postaci. [...] Zatem poznania miasta nie zawdzięczamy już wędrówkom wzdłuż głównych szlaków komunikacyjnych ani studiowaniu przewodników z ich zasobem wiedzy faktograficznej; poznaję miasto wtedy, gdy tworzę mapę punktów (a mapa taka będzie zapewne dla każdego inna), w których odsłaniają się przejścia między «górnym» a «dolnym» miastem" (Sławek, 2010, 23, 31).

${ }^{10} \mathrm{~W}$ tym sensie Nezvalowski flâneur reprezentuje postawę odległą od postawy modernistycznego przechodnia, który, jak dowodzi Elżbieta Rybicka, „nie może zatrzymać się w miejscu, wrosnąć i zakorzenić. Podstawą jego egzystencji jest ruch, miast stabilnego i trwałego fundamentu - domu, rodziny czy innych ośrodków przywiązania - posiada on tylko ruchome obrazy ulicy. Życie staje się dla niego przechodzeniem - bez celu, i mijaniem obok. «Filozofia przechodnia» daje mu wprawdzie wolność, ale z drugiej strony wykorzenia, czyniąc zeń wciąż przemieszczający się punkt widzenia. Przechodzień nie potrafi osiedlić się na stałe w konkretnym punkcie przestrzeni, gdyż to ograniczyłoby jego mobilną naturę, zatem jedyna rzecz, która mu pozostaje, to wrośnięcie w byt innych przechodniów, takich samych jak on. Ten «ruchomy» status przechodnia sygnalizuje jego nomadyczną, nieustaloną i niezwiązaną z miejscem tożsamość. Sytuacja przechodnia staje się więc alegorią kondycji człowieka miejskiego" (Rybicka, 2003, 209-210). 
že je člověkem, prošel jsem sta kilometrů pěší chůze a tisíce kilometrů duchového pohybu, než jsem zařídil před svýma očima Prahu, než jsem ji vybavil takovým druhem obývacích prostředků, jež by odpovídaly memu vkusu, než jsem ji vybavil takovým př́slušenstvím, abych po návratu do ní nemusil mít proti své vưli pocit člověka odkázaného na univerzální noclehárnu a aby ti, kdož budou sdílet po mém boku (není třeba, abych se s nimi kdy poznal) sousedství v tomto městě, na něž pohleděla Libuše ve chvíli, kdy existowalo ještě méně než v den, kdy jsem k němu poprvé blížil rapidní rychlostí vlaku, neměli pocit, že jsou pozváni do města, nad nímž visí mrak kouře (Nezval, 1981, 67-68).

Marzenie o powrocie do prapoczątków (czasami - do okresu dzieciństwa z jego „epistemologiczną pierwotnością” nieskażoną jeszcze poznawczymi nawykami, czasami, jak w cytowanej wypowiedzi, do epoki ante urbem conditam) zderza się w Nezvalowskim spacerowniku z pragnieniem, na pierwszy rzut oka przynajmniej, przeciwstawnym, a mianowicie: ze stanowczo wyrażonym postulatem zanurzenia praskiej przestrzeni w sieci kulturowych odniesień, nawiązań i koligacji. Antyteza ta traci jednak swą konfrontacyjną jednoznaczność, jeśli weźmie się pod uwagę, że, jak pisze Katarzyna Szalewska:

Pierwszym etapem w nowoczesnym doświadczaniu miasta jest zmysłowe, przedrefleksyjne zanurzenie się $\mathrm{w}$ tkance miejskiej i zdarzeniowości ulicy. To naiwne spojrzenie nie trwa jednak długo, [...] miasto bowiem jest przestrzenią nie tylko wielogłosową, lecz także wielokrotnie już odczytaną. Toteż zasadniczym rysem pejzażu urbanistycznego jest intertekstualność, współchodzenie, rozumiane jako intelektualne przemieszczanie się po przestrzeni już zinterpretowanej (Szalewska, 2017, 23).

Między oboma członami tej antynomii nie zachodzi zatem stosunek negacji, ale wynikania, a przyswojenie sobie niuansów i technik odczytywania zapisanych w tkance miejskiej kulturowych sensów uznać wypada za wyższy stopień strategii ,zadomawiania się”. Tyle tylko, że w tej sytuacji zawieszeniu ulega hasło „wędrówki bez celu”, a niektóre przynajmniej Nezvalowskie spacery okazują się precyzyjnie zaprogramowane, samo zaś ich podejmowanie służyć ma odtwarzaniu cudzego doświadczenia, budowaniu wspólnoty z poprzednikami i przerzucaniu mostów łączących przeszłość (pozytywnie wartościowaną) z budzącą rozczarowanie teraźniejszością:

Tak naše láska k Janu Nerudovi může se státi jednoho dne svědkem, že budeme hledati $\mathrm{s}$ trpělivostí člověka pohaněného tušením ono kluzké místo, kde si tento veliký stařec 
zlomil nohu. Tak vstoupíme do hospůdky, kde sedával Jakub Arbes, abychom spatřili barvu kouře a okenic, na něž upíral pohled, za kterým se rodila jeho romaneta. Od chvíle, kdy jsem se dočetl o Jaroslavu Vrchlickém, že stával brzy ráno před ještě neotevřeným krámem Ottova knihkupectví, má pro mne ta část Karlova náměstí, která je mezi Žitnou a Ječnou ulicí, nové kouzlo (Nezval, 1981, 12-13).

Niektóre z tych koligacji, o czym już była mowa, swym zasięgiem i pełnioną funkcją komunikacyjną nie wykraczają poza przebiegający w Czechach od czasów Odrodzenia Narodowego proces „literaturyzacji przestrzeni”, bazujący na eksponowaniu (na przykład za pomocą umieszczania na budynkach tablic pamiątkowych) miejsc związanych z życiem i twórczością praskich twórców. Nezval, przywołując te nazwiska i adresy, naśladuje zatem swych licznych poprzedników kodyfikujących krajobraz kulturowy miasta, a to swoiste poddanie się regułom stołecznej imagologii, polegające, najogólniej mówiąc, na rezygnacji z awangardowej (nad)nobilitacji cywilizacyjnych nowinek, dowodzi jedynie, że poeta, akceptując założenia surrealistycznej skomplikowanej gry z tradycją, która, wielu artystów wykluczając, wielu też wydobywa z niepamięci, złagodził nieco swe stanowisko i „dopuścił do głosu” również przedstawicieli potępianych czy nawet wyśmiewanych wcześniej nurtów i i konwencji.

Przypomnienie kilku pierwszoplanowych postaci z panteonu czeskiej literatury nie wyczerpuje oczywiście repertuaru wszystkich kulturowych odniesień, które leżą u podłoża projektowanej przez Nezvala reaktualizacji mitu Pragi ${ }^{11}$. Jak pisze Taborska, surrealistyczna potrzeba „odświeżenia” spetryfikowanej mitologii rodzi się ,z braku, z kryzysu, z pustki wywołanej nowym, które nie zastąpiło jeszcze w pełni starego. Nowi bogowie rodzą się i umierają. Od nowego mitu nie wymaga się, że będzie trwał wiecznie, przelotność jest jego naturą" (Taborska, 2007, 206). Wynika stąd, że

${ }^{11}$ Josef Vojvodík, analizując topos ,,miasta-ciała” i „miasta-książki” w tomiku wierszy Praha s prsty deště (Praga z palcami deszczu; 1936), podkreśla, że: „Nezval zde vysoce inovativním způsobem reaktualizuje «mytologii města», «estetiku města» symbolismu (Baudelaire, A. Blok, z českých básníků J. Zeyer, J. Karásek ze Lvovic, K. Hlaváček), především však z antiky (Cicero) pocházející a v pozdní renesanci (Leonardo da Vinci) a v manýrismu oživenou analogii míst paměti (loci) a obrazů paměti (imagines). Architektura města (Prahy), jeho - v tomto prŕípadě zcela konkrétní - domy, paláce, kostely, parky, ulice atd. fungují jako mnemo(tech)nické «znaky» (a «znamení») tohoto prostoru paměti. Akt (ro)zpomínání [...], je [...] vždy aktem ukazování, označování (ve smyslu latinské demonstrationis) a identifikování" (Vojvodík, 1996, 181). 
mity takie „nie wietrzeją w książkach, lecz rodzą się na ulicy z gorączki istnienia" (Taborska, 2007, 206). W przypadku Nezvalowskiej lektury „tekstu praskiego” jednak obrazy „skamieniałe w książkach” na prawach równych z ulotnością nagłych, przeżywanych w trakcie spacerów wizualnych olśnień współtworzą mitografię miasta, trzeba je jednak ,przewietrzyć”, gdyż dotychczasowy zasób literackich portretów Pragi nie spełnia oczekiwań autora, zarówno ze względu na swoją niepełność (nie wszystkie miejsca zostały zarejestrowane i opisane), jak i „nieprawidłowy” dobór dzieł, powodujący, że wiele istotnych atrybutów czeskiej stolicy nie znajduje w nich satysfakcjonującego odzwierciedlenia ${ }^{12}$ :

Pražská poezie, která čeká teprve na své zrození, a jejíž fantóm mne den ze dne více svádí, má na nejnečekanějších místech takové klece, v nichž by se naučil básník zpívat, zpívat nově, zpívat z hloubí pražských ozvěn, jimiž se nese k našemu sluchu noční vyzvanění hodin Starého Města, Malé Strany a Hradčan, klece, jejichž legendu nevypravuje už ani jeden ptáček. Jak je to podivuhodně vábivé a neschůdné, zaměniti občas soudobou literaturu, tak houževnatě upoutanou jen a jen děním, jež jsme svědky a obětmi, za nějaký ten svazek takových Tajností pražských. Podobná díla, aniž nám potřebují dáti to umělecké uspokojení, jež právem vyžadujeme, nabízejí v jistém směru více než pouhá literární díla. Je v nich zakleto ovzduší míst, kterými jsme si uvykli choditi již téměř bez vzrušení, a cosi nepomíjejícího ze zázračné imaginace lidu, jejíž pověrčivost není ze stanoviska básnického její nejhorší stránkou. I když jsou taková díla na mnohých místech nečitelná, v jejich zastaralosti se skrývá mnoho skutečné poezie, skutečné lásky $\mathrm{k}$ Praze, jež chce býti obnovena a postavena na nový základ (Nezval, 1981, 33-34).

Odpowiadającej surrealistycznemu stanowi ducha i wyobraźni atmosfery (aury?) miasta poszukiwać należy zatem nie w twórczości kanonicznej, ale w dziewiętnastowiecznej brukowej sensacyjno-fantastycznej prozie, której Nezval, podobnie jak inni przedstawiciele prądu inspirowani w tej dziedzinie „trywialnymi” fascynacjami Arthura Rimbauda, był zdeklarowanym miłośnikiem i która dostarczała mu impulsów do „przeprogramowania” spojrzenia na Pragę i nadania jej tajemniczości

${ }^{12}$ W efekcie, co odkrywa Petr Málek, w Praskim przechodniu: „Konkrétní topografie města je upozaděna a transformována na neurčitý topos vzpomínky, s níž koresponduje fragmentárnost $\mathrm{v}$ představeném prostoru i čase: flanérova roztržitá chůze vnějším městem, vedoucí přes nahodilé a překvapující zastávky, se transformuje v chůzi «přes znaky slov a knih». Putování a toulání se skutečným městem je nahrazováno procházením se knihami” (Málek, 2011, 216). 
zdolnej konkurować z cudownością przypisywaną przez francuskich nadrealistów Paryżowi. To on bowiem, oglądany przez pryzmat swych artystycznych reprezentacji, stanowił wówczas (przeprosić wypada za truizm tej konstatacji) archetypowy model „miasta mitycznego” i to do jego kulturowych portretów (i wzorców spacerowania po nim) niejednokrotnie odwołuje się autor, pragnący uczynić z nadwełtawskiej stolicy domenę uobecnionej surréalité.

$\mathrm{Na}$ intertekstualne powinowactwa łączące Praskiego przechodnia z wypracowaną przez surrealistów imaginacyjną retoryką miejską zwracają uwagę badacze, czasami nawet zarzucając poecie zbyt daleko posuniętą zależność od absolutyzowanych bez mała francuskich wzorców ${ }^{13}$. Zależności tej Nezval zresztą nie ukrywa, z jednej strony explicite przywołując jeden z owych kanonicznych tekstów, a mianowicie wspomniane już opowiadanie Apollinaire'a, z drugiej strony natomiast inicjując dyskusję na temat potencjału i granic pisania automatycznego, z którego koncepcją i poznawczą, by tak rzec, użytecznością autor, nigdy nieskrywający swej atencji do respektowania reguł ars poetica, polemizuje ${ }^{14}$. Przyznając zaś pierwszeństwo

${ }^{13}$ Cf. „Jak vydání Spojitých nádob (1932) A. Bretona ve Francii, tak i nová překladatelská praxe, jíž se Nezval bude věnovat spolu s J. Honzlem koncem r. 1934, nabídne jeho próze obnovenou teoretickou základnu a nové narativní modely, jako vždy bezprostředně přejímané a aplikované. U Nezvala se ted’ objevuje procházka městem, která bude od Aragonova Pařžského venkovana (1924) po Bretonovu Nadju jedním z «topoi» imaginární sféry surrealistů" (Dierna, 1996, 204).

${ }^{14} \mathrm{Cf}$. „Jsme u otázky takzvaných bdělých snů, které prý jsou výplodem čírého psychického automatismu, a je třeba rozhodnouti, do jaké míry vědomý proces, jímž je psaní, je jím ovlivněn. Rozhodně nelze mluviti při bdělých činnostech, k nímž náleží i poezie, o čirém psychickém automatismu. [...] Tak i při bližším zkoumání literárních automatických textů nám neujde, že jejich převažující společné vlastnosti a jejich dosti monotónní obdobný ráz je dán nikoliv jen impulsy, jež pronikají do bdění z nevědomí, nýbrž do veliké míry též obdobnou slovesnou technikou, zaostřením na obdobný estetický účinek, oněmi slohovými prostředky, jež přjejaly tyto texty z rimbaudovsko-lautréamontovské básnické tradice, prošlé duchem Apollinairovým a pak duchem dada, v němž programová účast náhody umožnila ustálení charakteristického, náhodným spojováním slovních prvků vyznačeného stylu” (Nezval, 1981, 45-46). Wątpliwości te, zaskakujące pod piórem surrealisty z lat trzydziestych, zobligowanego niejako do zaakceptowania jednego z najważniejszych pojęć z Bretonowskiego „regulaminu”, powracają po latach w rozważaniach Guy-Ernesta Deborda, twierdzącego, że „[p]řríčinou ideologického selhání surrealismu je, že vsadil na to, že nevědomí je konečně odhalenou velkou silou života. [...] Víme konečně, že nevědomá obraznost je chudá, že automatické psaní je monotónní a že sám žánr «neobyčejného», který z dálky oznamuje neměnný vzhled surrealismu, je nanejvýš nepřekvapivý. Formální věrnost tomuto stylu obraznosti 
w wytyczaniu ścieżek wiodących ku odkrywaniu nadrealnych aspektów praskiej przestrzeni i życia codziennego Apollinaire'owi (którego roli w kształtowaniu specyficznego oblicza czeskiej awangardy nie sposób, jak wiadomo, przecenić), poeta nie tyle eksponuje zasięg wykorzystanych przez siebie intertekstualnych eksploracji, podkreślając przy okazji literackie podglebie „odzyskiwanego” mitu Pragi, ile rzeczywiste źródła zapożyczenia skrzętnie ukrywa. W Praskim przechodniu nie pojawia się bowiem nazwisko Louisa Aragona, o pierwowzorze wszelkich tekstowych pasaży i spacerowników, czyli Wieśniaku paryskim, nie wspominając ${ }^{15}$. Tymczasem to w tym dziele właśnie, czy raczej za jego pośrednictwem, surrealiści:

odkryli Paryż - miasto surrealistyczne nie tylko w tym sensie, że jest to miasto przedziwnych egzystencji ludzkich, cudownych spotkań i niewiarygodnych zbiegów okoliczności, o czym wie również każdy cudzoziemiec, ale miasto nowin, w których czas najwolniej płynie, minione epoki ociągają się z odejściem i współżyją z dzisiejszą w murach, lokalach, rzeczach, obyczajach (Ważyk, 1976, 8) ${ }^{16}$.

Taki też obraz Pragi, w której przeszłość spotyka się z teraźniejszością, dostarczając tej ostatniej narzędzi lepszego i dogłębniejszego, na

nakonec vede k pravému opaku moderního stavu imaginárna: k tradičnímu okultismu" (Debord, 1957, 312-313. Cyt. za: Hrdlička, 2009, 102).

${ }^{15}$ Co ciekawe, interpretatorzy Praskiego przechodnia, niejako poddając się intentio auctoris, również uwypuklają genetyczne związki tekstu przede wszystkim z praskim opowiadaniem Apollinaire'a (osłabiając tym samym znaczenie relacji łączących Nezvalowski tekst z dziełem Aragona): „Pojem, či spíš topos «pražský chodec» je jistě nedílnou součástí pražského kontextu, a to nejen proto, že stojí v záhlaví dvou pražských textů - Apollinairova [...] a Nezvalova o třicet šest let pozdějšího [...].«Pražský chodec», zejména Nezvalův, prochází «básnicky» [...] městem a proživá místa, jež patří k základním toposům pražského kontextu. Apollinaire v Pražském chodci prrímo říká, že nové umění spočívá v chůzi - básnické chůzi městem” (Hodrová, 2006, 190). Najbardziej znany praski „literacki flâneur”, Angelo Maria Ripellino, dowodzi zaś, że devětsilowscy poeci „niczym bractwo czarowników, biegali nocą po nadwełtawskim mieście, chłonąc jego urok przez filtr przywoływanych na pamięć wierszy Strefy. Na placach, na mostach, na nabrzeżu słyszeli w wyobraźni kroki i głos francuskiego poety. Nie potrafili wyobrazić sobie tego zbiorowiska cudów bez jego gadatliwej obecności” (Ripellino, 1997, 357; cf. też: Koschmal, 1997, 360-376).

${ }^{16}$ Zdaniem Agnieszki Taborskiej: „To, że surrealiści uważali się za apostołów epoki nowoczesnej, było konsekwencją ich buntu wobec przeszłości. Modernizujące się miasto fascynowało surrealistyczną literaturę i kino. Wieśniak paryski, przedstawiający pierwszy i najbarwniejszy obraz mitologii nowoczesności, rysujący drogę wylęgania się nowej estetyki - jak inne powieści o surrealistycznym Paryżu - wyrósł z zamiłowania do włóczęgi po dziennym i nocnym mieście" (Taborska, 2007, 205). 
„odnowionych fundamentach zbudowanego" odczytywania zapisanych w historii (alternatywnej i codziennej oczywiście, przeciwstawianej tutaj jej oficjalnej wykładni) i pamięci miasta sensów, często zresztą, co wyraźnie widać we wcześniej cytowanych fragmentach dzieła, „mierzonych paryską miarą" i w konkurencji tej zyskujących palmę pierwszeństwa, Nezval pragnie zaoferować swemu czytelnikowi, by ten, „odpowiednio pouczony" wiedział, co i jak zobligowany jest deponować w swoich wspomnieniach.

Zwrot w stronę praskiego dyskursu memorialnego, charakterystyczny, jak podkreślają badacze, dla modernistycznego (sygnowanego nazwiskami Waltera Benjamina, Siegfrieda Kracauera czy Franza Hessla ${ }^{17}$; trudno nie zauważyć w nich czołowych „,filozofów flâneuryzmu”) kodu przeżywania przestrzeni zurbanizowanej, z jednej strony, ze względu na silne powiązanie pamięci z wyobraźnią (w przypadku Nezvalowskiej surrealistycznej niechęci do mimetyzmu dodatkowo wyeksponowane), odbierające jej wymiar „twardej, materialnej realności”, co, jak dowodzi Renate Lachmann w pracy opatrzonej znamiennym tytułem Memoria fantastica, przemienia ją w obszar o charakterze symulakrycznym ${ }^{18}$, z drugiej strony wyznacza ,pożądany portret” owego czytelnika. Odbiorca Praskiego przechodnia nie tylko bowiem powinien być mieszkańcem stolicy, lecz także znać ją na tyle dobrze, by dostarczane mu, szczątkowe najczęściej, wskazówki topograficzne (Nezval, a to w przypadku spacerownika może budzić zdziwienie, unika tu drobiazgowej deskryptywności) spożytkować

${ }^{17}$ Jak bowiem pisze Magdalena Saryusz-Wolska: „Kiedy czytamy dzisiaj miejskie teksty Waltera Benjamina [...] eseje Kracauera [...] czy berlińskie obserwacje Franza Hessla [...] okazuje się, że niejednokrotnie są to teksty pamięci par excellence: wspomnienia, pojedyncze kadry z przeszłości, obrazki z młodości itd. Przestrzeń miejska u modernistycznych autorów pełna jest uzupełniających się sprzeczności: koncentracji na przeszłości i przyszłości, spojrzeń na przedmioty bliskie i odległe, nostalgii i złości” (Saryusz-Wolska, 2011, 133).

${ }^{18} \mathrm{Cf}$. „Mnemonické prostory bud' vycházejí ze skutečného světa, anebo jsou to prostory fantazijní. V obou př́padech jsou to jen představované prostory mnemotechniky. Stavebně provedená divadla paměti, její prostory a architektury, napodobují imaginární prostory paměti. Obrazně znázorněné architektury paměti [...] se vztahují bud' k «postaveným» nápodobám [...], anebo jsou nápodobami imaginárních fantazijních prostorů, respektive zobrazením rétoricky mnemotechnických návodů. V takovém pojetí je architektura města simulakrem coby kulisa divadla paměti. Tudíž má stejný status jako imaginární loci - budovy, labyrinty, parky. Coby simulakrum získává město, konkrétní město, tuto fiktivní dimenzi, která je vlastně teprve zmocňuje stát se místem paměti” (Lachmann, 2002, 43-44). 
na aktywizację własnych przebiegów memorialnych wykorzystujących zarówno prywatne, jak i kulturowe doświadczenie kontaktu z rodzimym miastem. W rezultacie toponimy, które w tekście pojawią się w swoistej „nadreprezentacji”,

nejenže utvářejí skutečnost, ale někdy dokonce nahrazují děj a události. V Nezvalově mnemotechnice jsou názvy natolik obohaceny o př́běhy a vzpomínky, že jejich pouhá zmínka v nás vyvolává množství pocitů (Tippnerová, 2014, 207).

Anja Tippnerová powołuje się w tych rozważaniach na „instrukcje”, które kontynuatorom swej formuły „miastopisania” pozostawił Walter Benjamin, równie przydatne jednak okazać się tu mogą konkluzje zaproponowane przez Michela de Certeau. W jego oczach bowiem nazwy własne, aczkolwiek w podstawowej funkcji, służą przede wszystkim porządkowaniu i hierarchizacji przestrzeni, w miarę upływu czasu

tracą stopniowo, podobnie jak zużyte monety, wyrytą w nich wartość; niemniej jednak możliwość tworzenia znaczenia jest w nich trwalsza niż ich pierwotne przeznaczenie. [...] Otwierają się one na wieloznaczności, jakimi obdarzają je przechodnie; odrywają się od miejsc i służą jako wyobrażone miejsca spotkań metaforycznym podróżom, które określają nie z powodów związanych z ich pierwotnym znaczeniem, ale z powodów znanych/nieznanych przechodniom (de Certeau, 2008, 105) ${ }^{19}$.

Innymi słowy, nazwy te stając się „wywoływaczami” wspomnień (wspólnotowych i indywidualnych), ułatwiają oswojenie, zawłaszczenie i „uczłowieczenie” miejskiego terytorium (należy pamiętać, że surrealiści, doskonale znając alienacyjny wymiar procesów urbanizacyjnych, starali się miasto „naturalizować”20), kondensują heterogeniczne sensy

${ }^{19}$ Elżbieta Rybicka, włączając dyskurs memorialny w obręb założeń geopoetyki (a założenia te Praski przechodzień niewątpliwie realizuje), stwierdza, że „,[s]zczególną pozycję w [...] literaturze miejsc zajmują toponimie. Nazwa bowiem i pamięć przeszłości w niej ukryta wydaje się jednym z najważniejszych elementów współczesnego dyskursu pamięci miejsc. Jej rola nie ogranicza się [...] do lokalizacji przestrzennej (choć te precyzyjne umiejscowienia w prozie współczesnej również wymagają osobnego namysłu). [...] Nazwa stanowi [...] szczelinę wiodącą do złóż pamięci, ujście w głąb pamięci prywatnej, a zarazem [...] pamięci kulturowej miejsca" (Rybicka, 2014, 318, 320).

${ }^{20}$ Tippnerová, pisząc o typowym dla surrealistycznej wizji świata postulacie przywracania środowiska miejskiego naturze, wiąże ją z benjaminowskim w swej istocie marzeniem o „zabłądzeniu” w mieście: „Nezval zde uskutečňuje poetiku bloumání a bezcílného procházení, pohybu, který je poháněn naději na «trouvaille» nebo na setkání, jež se může stát 
i asocjacje oraz stanowią zalążki bazujących na owych wspomnieniach opowieści, które „przełożone na język literatury” czynią miasto „prawdziwie własnym".

W Praskim przechodniu podobnych ,samorodnych” miejskich legend, anegdot i mikropoematów nie brakuje, Nezval dodatkowo inkrustuje relację o wędrówkach po Pradze fragmentami swych wierszy, rozbijając genologiczną koherencję tekstu i nadając mu kolażowo-sylwiczny charakter, zbliżony do, często w opowieściach miejskich stosowanej, techniki bricolage “ $u$ (cf. de Certeau, 2008, 108). „Urywkowość” czy raczej swoista afinalność tych narracyjnych i lirycznych etiud, zapraszających czytelnika do podjęcia gry z autorem i dopełniania brakujących „,ciągów dalszych" i zakończeń, koresponduje z opisywaną w dziele taktyką spacerowania, w której: „Kontinuální pohyb je vystřídán pohybem fragmentárně trhavým" (Koschmal, 1997, 365) i gdzie flâneura zatrzymują tylko zharmonizowane z jego stanem ducha i emocjonalnymi potrzebami komponenty miejskiego pejzażu i zachodzące w nim wydarzenia. $Z$ tej zależności Nezval zdaje sobie zresztą sprawę, niejako, avant la lettre, przeczuwając analizowane przez Benjamina i de Certeau ${ }^{21}$, określane dziś za pomocą terminu „werbomotoryka”, zespolenie (ewentualnie graniczące

podnětem ke vzniku básně. Přitom se má město proměnit zpět na přírodu, má opět stát se lesem a loukou, chodec se v něm má ztratit podobně jako v tmavém lese” (Tippnerová, 2014, 208).

${ }^{21}$ Pokrewieństwo zaproponowanej przez de Certeau koncepcji tekstowego charakteru spacerowania z Nezvalowską włóczęgą podejmowaną w celu odnalezienia w mieście znaków nadrzeczywistości nie musi wydawać się nadinterpretacyjnym anachronizmem. Pionier antropologii codzienności uzasadniał bowiem swe tezy za pomocą argumentów przejętych z bliskiej surrealistom teorii psychoanalitycznej: „Figury owych ruchów (synekdochy, elipsy itd.) są charakterystyczne jednocześnie dla «symboliki nieświadomego» oraz «niektórych typowych chwytów subiektywności przejawiającej się w dyskursie». Podobieństwo między «dyskursem»a marzeniem sennym wynika ze stosowania takich samych «chwytów stylistycznych»: obejmuje także praktyki związane z chodzeniem [...]. W tej perspektywie, przybliżywszy wędrowne procesy do formacji językowych, można je umieścić po stronie wyobrażeń onirycznych albo przynajmniej wyłonić na owym drugim brzegu to, co w praktyce przestrzennej jest nieodłączne od wyśnionego miejsca. Chodzenie to niedostatek miejsca. Jest to nieograniczony proces bycia nieobecnym i poszukiwania czegoś własnego. [...] Tożsamość, jaką zapewnia owo miejsce, jest tym bardziej symboliczna (ustanawiana), że pomimo różnic godności i zysków wśród mieszkańców napotykamy tu wyłącznie rój przechodniów, sieć mieszkań znajdujących się w obiegu, dreptanie po tym, co wydaje się własne, świat dzierżaw nawiedzonych przez jakieś nie-miejsce albo miejsca wyśnione" (de Certeau, 2008, 103-104). 
z identyfikacją porównanie) czynności chodzenia (dysponującego własną retoryką i zasobem tropów stylistycznych) z pisaniem:

\begin{abstract}
Nebudu již dělat z deseti světových stran dvouhodinové túry, abych si na nich uvědomil délku pražských ulic a abych ji uváděl v poměr s délkou mých souvětí, v jejichž zákrutech jsem se snažil rozvinout několik domovních bloků, k nimž se rád vracím a jež jsem od sebe oddělil jak noční ostrůvky neproniknutelným syntaktickým zdivem. Tato sugestivní metoda [...] se mi zdá býti poněkud zdlouhavá zvláště vzhledem k rychlému mizení zásob papíru, který je určen na rychlé ukončení této knihy. Budu se nyní přenášet z místa na místo, aniž budu odůvodňovati, kterou tratí jsem tam dorazil, a budu tam prodlívati po krátkou dobu, které je třeba k zablesknuti. Po zevrubném zasvěcení čtenáře do svých vnitřních metod, jimiž se zmocňuji vzrušující stránky města Prahy, mám plné právo k takovému přelétání (Nezval, 1981, 80).
\end{abstract}

Oba - spacerowanie i literacka reprezentacja - narzędzia oswajania, poznawania i emocjonalnego doświadczania miasta pozwalają Nezvalowi odkrywać poetyckie (immanentnie w niej obecne, a nie - narzucane z zewnątrz) nacechowanie przestrzeni praskiej. $Z$ tej zaś perspektywy patrząc, wszelkie opisy i opowieści miejskie zyskują osobliwy status ,intersemiotycznego przekładu”, w którym „oryginalny śpiew miasta” zostaje jedynie (wtórnie!) zwerbalizowany przez znającego jego „sekretny język” tłumacza. „Vltava zpívá si své písně beze slov / Vltava zpívá a já skládám k písním slova" (Nezval, 1981, 48) oznajmia czytelnikowi Nezval w jednym z zamieszczonych w spacerowniku wierszy, uznając swą podległość w stosunku do bardziej autentycznego, gdyż niepoddanego sztucznym regułom ars poetica głosu, którym do wtajemniczonych przechodniów od wieków przemawia Praga. Usłyszenie i zarazem zdobycie prawa do translacji tego głosu wymaga jednak odejścia od absolutyzowania awangardowych wyobrażeń o idealnym, bazującym na czysto racjonalnej geometrii linii i kątów prostych porządku miejskim (cf. Kornhauser, 2017, 32) i przypomnienia, że bardziej adekwatną metaforą nowoczesnego,,miastopisania” pozostaje pozbawiony punktów orientacyjnych, zdecentralizowany, nigdy ostatecznie nieukończony i otwarty na wiele możliwych odczytań, labirynt ${ }^{22}$.

${ }^{22} \mathrm{Cf}$. „Labyrint je současně starým metaforickým modelem písma, v jehož abstraktních formacích se umělec od dob renesance pokoušel «postihnout jednotu rozpadajícího se světa». V Benjaminově přehodnocení nabývá labyrint nového významu: textura labyrintického zaplétání oklik a bludných cest jako model textu, textu jako labyrintu, se stává zároveň modelem «labyrintického» jazyka, jenž nemaje středu - jistoty významu - se dehierarchizuje 


\section{Literatura}

Aragon, L. (2015). Wieśniak paryski. Przeł. A. Międzyrzecki. Warszawa: Państwowy Instytut Wydawniczy.

Breton, A. (1976). Manifest surrealizmu. Przeł. A. Ważyk. W: Surrealizm. Teoria i praktyka literacka. Red. A. Ważyk. Warszawa: Czytelnik, s. 73-74.

Carrouges, M. (2015). André Breton a základy surrealismu. Přel. J. Vaněk. Praha: Malvern.

de Certeau, M. (2008). Wynaleźć codzienność. Sztuki działania. Przeł. K. Thiel-Jańczuk. Kraków: Wydawnictwo Uniwersytetu Jagiellońskiego.

Debord, G. (2006). Oeuvres. Paris: Gallimard.

Dierna, G. (1996). Způsoby a tvary touhy: Nezvalova próza z let surrealismu. W: Český surrealismus 1929-1953. Ed. L. Bydžovská, K. Srp. Praha: Argo, s. 200-213.

Frydryczak, B. (2002). Świat jako kolekcja. Próba analizy estetycznej natury nowoczesności. Poznań: Wydawnictwo Fundacji Humaniora.

Hocke, G.R. (2001). Svět jako labyrint. Manýrismus v literatuře. Přel. J. Brynda. Praha: Triáda/H\&H.

Hodrová, D. (2006). Citlivé město (eseje z mytopoetiky). Praha: Akropolis.

Hrdlička, J. (2009). Obraz negace. Surrealismus a kritika obrazu. W: M. Langerová, J. Vojvodík, A. Tippnerová, J. Hrdlička. Symboly obludnosti. Mýty, jazyk a tabu české postavantgardy 40.-60. let. Praha: Malvern, s. 79-108.

Janicka, K. (1985). Światopoglad surrealizmu. Jego założenia i konsekwencje dla teorii twórczości i teorii sztuki. Warszawa: Wydawnictwa Artystyczne i Filmowe.

Kornhauser, J. (2017). Awangarda. Strajki, zaktócenia, deformacje. Kraków: Wydawnictwo Uniwersytetu Jagiellońskiego.

Koschmal, W. (1997). Město (Praha) a nevědomí (Apollinaire - Nezval). „Česká literatura" č. 4, s. 360-376.

Lachmann, R. (2002). Memoria fantastika. Přel. T. Glanc. Praha: Herrmann\&synové.

Málek, P. (2011). Město. W: Heslář české avantgardy. Estetické koncepty a proměny uměleckých postupi v letech 1908-1958. Ed. J. Vojvodík, J. Wiendl. Praha: Togga, s. 199-224.

Nezval, V. (1981). Pražský chodec. Praha: Československý spisovatel.

Ripellino, A.M. (1997). Praga magiczna. Przeł. H. Kralowa. Warszawa: Państwowy Instytut Wydawniczy.

Rybicka, E. (2003). Modernizowanie miasta. Zarys problematyki urbanistycznej w nowoczesnej literaturze polskiej. Kraków: Universitas.

Rybicka, E. (2014). Geopoetyka. Przestrzeń i miejsce we wspótczesnych teoriach i praktykach literackich. Kraków: Universitas.

a ukazuje jako nestabilní a ambivalentní. Takové čtení je možné teprve v kontextu projektu, v němž zkušenost velkoměsta moderny je čtena jako písmo" (Málek, 2011, 203; cytat wewnętrzny pochodzi z: Hocke, 2001, 132). 
Saryusz-Wolska, M. (2011). Spotkania czasu z miejscem. Studia o pamięci i miastach. Warszawa: Wydawnictwo Uniwersytetu Warszawskiego.

Sławek, T. (2010). Miasto. Próba zrozumienia. W: Miasto w sztuce - sztuka miasta. Red. E. Rewers. Kraków: Universitas, s. 17-69.

Szalewska, K. (2009). O „flâneura” spojrzeniu w przeszłość albo o antyturyście: (na marginesie cyklu Szary Paryż Bogdana Konopki). „Panoptikum” nr 8, s. 45-60.

Szalewska, K. (2017). Urbanalia. Miasto i jego teksty. Humanistyczne studia miejskie. Gdańsk: Słowo/obraz/terytoria.

Taborska, A. (2007). Spiskowcy wyobraźni. Surrealizm. Gdańsk: Słowo/obraz/terytoria.

Tippnerová, A. (2014). Permanentní avantgarda? Surrealismus v Praze. Přel. M. Brunová. Praha: Academia.

Turner, C. (2010). Palimpsest czy przestrzeń potencjalna? W poszukiwaniu słownictwa dla widowiska w miejscu znalezionym. Przeł. M. Gołaczyńska. W: Miasto w sztuce-sztuka miasta. Red. E. Rewers. Kraków: Universitas, s. 238-255.

Vojvodík, J. (1996). Proměny těla. K sémantice tělesnosti v surrealistické lyrice Vitězslava Nezvala. W: Český surrealismus 1929-1953. Ed. L. Bydžovská, K. Srp. Praha: Argo.

Ważyk, A. (1976). Przedmowa. W: Surrealizm. Teoria i praktyka literacka. Antologia. Red. A. Ważyk. Warszawa: Czytelnik, s. 5-36. 